\title{
Helicobacter pylori promotes apoptosis, activates cyclooxygenase (COX)-2 and inhibits heat shock protein HSP70 in gastric cancer epithelial cells
}

\author{
Aneta Targosz • Tomasz Brzozowski • Piotr Pierzchalski • \\ Urszula Szczyrk • Agata Ptak-Belowska • \\ Stanislaw Jan Konturek • Wieslaw Pawlik
}

Received: 3 January 2012/Revised: 5 March 2012/Accepted: 2 May 2012/Published online: 19 May 2012

(C) The Author(s) 2012. This article is published with open access at Springerlink.com

\begin{abstract}
Objective Apoptosis plays an important role in the regulation of gastric epithelial cell number and gastrointestinal disorders induced by Helicobacter pylori ( $\mathrm{Hp}$ ). Heat shock proteins (HSPs) are involved in cell integrity, cell growth and in gastric mucosa colonized by $\mathrm{Hp}$. COX-2 was implicated in $\mathrm{Hp}$-induced carcinogenesis but the effects of this germ and CagA cytotoxin on HSP70, COX-2, Bax and Bcl-2 in gastric cancer epithelial cells have been little studied.

Material and methods We determined the expression for HSP70, Bax and Bcl-2 in human gastric epithelial MKN7 cells incubated with live strain $H p(\operatorname{cag} A+v a c A+)$ with or without co-incubation with exogenous CagA and NS398 , the selective COX-2 inhibitor. After 3-48 h of incubation, the expression of HSP70, COX-2, Bax and Bcl-2 mRNA and proteins were determined by RT-PCR and immunoprecipitation.

Results $H p$ inhibited expression for HSP70 and this was significantly potentiated by exogenous CagA. Co-incubation of epithelial cells with $H p$, without or with CagA increased Bax expression and simultaneously decreased expression for Bcl-2. The increase in COX-2 mRNA and Bax expression were significantly inhibited by NS-398. We
\end{abstract}

Responsible Editor: Ian Ahnfelt-Rønne.

\footnotetext{
A. Targosz · T. Brzozowski $(\bowtie) \cdot$ U. Szczyrk ·

A. Ptak-Belowska · S. J. Konturek · W. Pawlik

Department of Physiology, Jagiellonian University Medical

College, 16 Grzegorzecka Str., 31-531 Cracow, Poland

e-mail: mpbrzozo@cyf-kr.edu.pl

P. Pierzchalski

Department of Medical Physiology, Faculty of Health Sciences,

Jagiellonian University Medical College, Cracow, Poland
}

conclude that Hp promotes apoptosis in adenocarcinoma gastric epithelial cells in vitro and this is associated with activation of COX-2 and inhibition of HSP70.

Keywords Helicobacter pylori - Apoptosis - CagA . Heat shock protein 70 . Cyclooxygenase-2

\section{Introduction}

The gastric mucosa integrity depends on a balance between the renewal and the death of damaged or aged cells. Apoptosis, first proposed by Kerr et al. [1] in 1972, plays a complementary but opposite role to that of cell proliferation in regulation of normal growth and development of animal and human tissue. Gastric mucosa shows a high rate of renewal. The surface mucosal cells are constantly exfoliating into the gastric lumen, with a 3-5 day renewal rate under normal physiological conditions. Apoptosis has been reported to take place in all regions of stomach, occurring predominantly in the upper part of the gastric glands and involving 2-3\% of all epithelial cells [2, 3]; however, this process in gastric cancer cells has been little investigated.

The regulation of apoptosis is a complex process that includes the activation of various apoptosis-related proteins such as the Bcl-2 family, p53, Fas and its ligand (FasL). The Bcl-2 family is one of the most thoroughly studied groups of proteins involved in the regulation of apoptosis under normal conditions. Some members of the Bcl-2 family, such as Bax, Bad or Bid promote apoptosis, whereas the other members, such as Bcl-2 and Bcl- $\mathrm{x}_{1}$ were shown to inhibit this process [4-6]. Many bacterial pathogens have been identified as factors influencing the process of apoptosis in vivo and in vitro. Among the 
bacterial factors, the most important is Helicobacter pylori $(H p)$, which is a spiral, Gram-negative microaerophilic bacterial pathogen that has been categorized by WHO as a class I carcinogen, infecting the stomach of about $50 \%$ of the world's population [7, 8]. At present, the mechanisms by which $H p$ affects apoptosis in gastric epithelial cells still remains unclear because of the lack of availability of normal human epithelial cell line suitable to study these aspects in vitro conditions.

The major disease-associated genetic difference in $\mathrm{Hp}$ induced the upper gastrointestinal disorders is the presence $(c a g+$ and $v a c A+)$ or absence $(\operatorname{cag} A-$ and $v a c A-)$ of the pathogenicity island (cag-PAI), which is a locus of about 40-kilobase containing up to 27-31 genes [9, 10]. One strain-specific $H p$ locus that has been associated with an increased risk of carcinogenesis is the vacA gene, which encodes a secreted bacterial cytotoxin identified as VacA. When added to mammalian cells in vitro, cytotoxin VacA induces multiple structural and functional alterations in the cell, the most prominent of which is the formation of large intracellular vacuoles [11-13]. Cytotoxin-associated gene $\mathrm{A}(\operatorname{cagA})$ is the only known $\mathrm{Hp}$-protein translocated into host cells followed by tyrosine phosphorylation through host protein kinases. $H p$ strains possessing the $\operatorname{cag} A$ gene has been linked to an increased risk of the development of peptic ulceration and gastric cancer in infected individuals. However, this protein is not critical to the pathogenesis of the disease, due to the fact that many strains, which possess CagA do not cause disease and some strains that are associated with disease do not express $\operatorname{cagA}[14,15]$. The cag-PAI encodes a type IV secretion system (TFSS) that forms a syringe-like structure, which is used to translocate the bacterial proteins into different types of eukaryotic cells. Once introduced into the host cells, bacterial toxins promote the synthesis and secretion of chemokines, such as interleukin-8 (IL-8) $[16,17]$. Moreover, TFSS activates intracellular signaling including $\mathrm{NF} \kappa \mathrm{B}$ and specific kinases such as mitogenactivated kinase (MAPK), that subsequently promote the transcription of genes responsible for inflammation, proliferation or apoptosis [18].

Heat shock proteins (HSPs) represent a nearly universal phylogenetically and highly conserved family of proteins that form the machinery able to prevent damage to the cell structure from a variety of environmental stresses and unfavorable conditions. HSPs act as molecular chaperons folding newly synthesized cell proteins and assisting in the refolding of damaged proteins. In particular, HSP70 is located in all cellular compartments including the mitochondria, endoplasmic reticulum, cytosol and nucleus [1921]. HSP70 can be produced in response to environmental changes such as heat, ischemia, heavy metals, ethanol, toxin, oxidants, various viral and bacterial infections and it is believed that their primary function is to protect the body's cells against stress [22].

Cyclooxygenase (COX), the rate-limiting enzyme in the conversion of arachidonic acid to prostaglandin $\mathrm{H}_{2}$, is the main target of non-steroidal anti-inflammatory drugs (NSAIDs). Two isoforms of this enzyme have been identified: COX-1 and COX-2. The isoform COX-1 is constitutively expressed in most tissues and is involved in the production of prostaglandins (PG) to maintain normal physiological functions. COX-2 is involved in inflammation and triggered by mitogens, cytokines, hormones and growth factors. Several recent studies suggest that COX-2 might be an important factor in carcinogenesis, and COX-2 inhibitors were shown to possess anticancer effects [23]. Since $H p$ CagA and VacA positive and negative strains were reported to inhibit [24], and in some studies, to promote, the apoptosis in gastric mucosal cells in vivo and in vitro [25-29], we studied the effect of incubation with $H p$ of human MKN7 adenocarcinoma cell line with relation to expression HSP70, COX-2 and apoptosis. The purpose of our present study was several folds: (1) to determine the effect of live $H p$ strain expressing $\operatorname{cagA}$ and $v a c A$ on the expression of HSP70 in gastric epithelial MKN7 cells; (2) to examine the apoptosis rate in these cells by assessing the expression of mRNA for Bax and Bcl-2; (3) to compare the effect of cell incubation with $H p$ strain expressing cagA and vacA applied alone or in combination with exogenous CagA protein on the expression of HSP70, Bax and Bcl-2 in MKN7 cells; (4) to compare the effect of $H p$ strain expressing $\operatorname{cag} A$ and $v a c A$ and strains negative for $\operatorname{cag} A$ and vacA coincubated with or without the NS-398 on mRNA expression for COX-2 and apoptotic proteins Bax and Bcl-2 in MKN7 cells.

\section{Materials and methods}

All experimental procedures performed in this study were run in accordance to the Helsinki Declaration and approved by the Jagiellonian University Institutional Animal Care and Use Committee.

\section{Bacterial strains and their characterization}

Strains of $\mathrm{Hp}$ used in this study were isolated from gastric biopsy specimens of the patients with gastric ulcer who underwent upper endoscopy. The bacteria were grown on Columbia Agar supplemented with $5 \%$ fresh horse blood (BioMerieux, Marcy l'Etoile, France). The plates were incubated under microaerophilic conditions at $37^{\circ} \mathrm{C}$ for 3-5 days.

Genomic DNA was isolated from $H p$ strains obtained from patients using DNAzol Reagent (Life Technologies, 
NY, USA) according to the manufacturer's protocol. For each single PCR reaction, $20 \mu \mathrm{g}$ of DNA was used. Specific primers for the detection of $\operatorname{cagA}$ and vacA were synthesized by Sigma-Aldrich (St. Louis, USA). CagA and $v a c A$ positive and negative strains of $H p$ were used in experiments described in this study. Stock cultures were maintained at $-70{ }^{\circ} \mathrm{C}$ in Brucella Broth supplemented with $10 \%$ fetal bovine serum and $10 \%$ glycerol. Prior to the incubation with MKN7 cells, bacterial strains of $H p$ were suspended in sterile PBS.

Cell line and culture conditions

MKN7 human gastric carcinoma cells were grown in RPMI 1640 medium (Sigma-Aldrich, USA) supplemented with $10 \%$ fetal bovine serum at $37{ }^{\circ} \mathrm{C}$ with $5 \% \mathrm{CO}_{2}$ and humidified atmosphere in absence or in the presence of $\mathrm{Hp}$ alone or in combination with the recombinant $\mathrm{CagA}$ (OraVax Inc., Cambridge, USA) or NS-398, a selective COX2 inhibitor. Before the experiments cells were seeded on $100 \mathrm{~mm}$ culture dish in RPMI 1640 with addition of $2 \%$ fetal bovine serum without antibiotics. MKN7 cells were infected with $1 \times 10^{9}$ of live $H p$ per dish (calculated to approximately $300 \mathrm{Hp}$ bacteria per cell) and co-incubated with $10 \mu \mathrm{g}$ of CagA per $1 \mathrm{ml}$ of RPMI medium or with $50 \mathrm{mM}$ of NS-398.

Determination of Bax and COX-2 expression by RTPCR

After 3, 6, 24 and $48 \mathrm{~h}$ of incubation the cells were harvested and the total cellular RNA was isolated using Trizol Reagent (Invitrogen, Carlsbad, USA) according to the manufacturer's protocol. Following precipitation, RNA was resuspended in RNase-free water and its concentration was estimated by the absorbance at $260 \mathrm{~nm}$ wavelength. The RNA integrity in each sample was confirmed by $1 \%$ agarose-formaldehyde gel electrophoresis and ethidium bromide staining. Aliquoted RNA samples were stored at $-80{ }^{\circ} \mathrm{C}$ until analysis. The synthesis of the first strand cDNA was performed with Reverse Transcription System (Promega, Madison, USA) using $2 \mu \mathrm{g}$ of RNA. For the PCR, $2 \mu$ of cDNA and oligo primers were used. All PCR reactions were carried out using a Promega PCR reagents. The DNA was amplified in the thermal cycler (Biometra T3, Berlin, Germany) with 20 cycles for $\beta$-actin (denaturation at $95{ }^{\circ} \mathrm{C}$ for $1 \mathrm{~min}$, annealing $54{ }^{\circ} \mathrm{C}$ for $1 \mathrm{~min}$ and extension for $72{ }^{\circ} \mathrm{C}$ for $2 \mathrm{~min}$ ), 29 cycles for Bax (denaturation at $94{ }^{\circ} \mathrm{C}$ for $45 \mathrm{~s}$, annealing $55{ }^{\circ} \mathrm{C}$ for $45 \mathrm{~s}$ and extension for $74{ }^{\circ} \mathrm{C}$ for $2 \mathrm{~min}$ ), 35 cycles for COX-2 (denaturation at $94{ }^{\circ} \mathrm{C}$ for $1.5 \mathrm{~min}$, annealing $58{ }^{\circ} \mathrm{C}$ for $1.5 \mathrm{~min}$ and extension for $72{ }^{\circ} \mathrm{C}$ for $1.5 \mathrm{~min}$ ). Specific primers were synthesized by Sigma-Aldrich (St. Louis, USA). The following human primers were used: $\beta$-actin s-5'AGC GGG AAA TCG TCG GTG $3^{\prime}$, a- $5^{\prime}$ GGG TAC ATG GTG GTG CCG $3^{\prime}$, Bax s-5' TGG CAG CTG ACA TGT TTT CTG 3 , a- $5^{\prime}$ CGT CCC AAC CAC CCT GGT CT $3^{\prime}$, Bcl-2 s-5' GAC AGC CAG GAG AAA TGA AA $3^{\prime}$, a-5' GAC TTC TTC CGC CGC TAC $3^{\prime}$, COX-2s-5' AGA TCA TCT CTG CCT GAG TA $3^{\prime}$, a-5' CCT TCT TAA CCT CTC CTA TTA TA $3^{\prime}$.

PCR products were detected by electrophoresis on $2 \%$ agarose gel containing ethidium bromide. Location of the predicted PCR products was confirmed using O'Gene Ruler 50 bp DNA Ladder (Fermentas Life Sciences, San Francisco, USA) as a standard-size marker.

\section{Immunoprecipitation}

Protein extracts from MKN7 cells were prepared as described by Cha et al. [30]. Samples containing $10 \mu \mathrm{g}$ of proteins were incubated for $4 \mathrm{~h}$ at $4{ }^{\circ} \mathrm{C}$ on a shaking platform with $5 \mu \mathrm{l}$ of primary goat polyclonal anti HSP70, rabbit monoclonal anti Bax, and mouse polyclonal anti Bcl-2 antibodies. Five microliters of A-agarose were added to each sample and samples were incubated overnight at $4{ }^{\circ} \mathrm{C}$. Complexes were washed three times with RPB-buffer (150 mM NaCl, $1 \%$ NP-40, $0.5 \%$ deoxycholate, $0.1 \%$ SDS, $50 \mathrm{mM}$ Tris $\mathrm{pH} 8$ ). Then $10 \mu \mathrm{l}$ of western blot sample buffer $(0.1 \mathrm{M}$ Tris- $\mathrm{HCl} \mathrm{pH} 6.8$, $4 \%$ SDS, $20 \%$ glycerol, $2 \%$ mercaptoethanol, $0.2 \%$ bromophenol blue) was added to each pellet, boiled for 5 min at $95{ }^{\circ} \mathrm{C}$ and loaded on the $12 \%$ SDS-polyacrylamide gel. After electrophoresis and transfer of the samples, the PVDF membrane (BIORAD, Hercules, USA) was blocked with $5 \%$ non-fat dried milk in PBS for $2 \mathrm{~h}$ at room temperature. Blocking procedure was followed with $1 \mathrm{~h}$ exposure to primary antibody diluted 1:1000 and secondary antibody anti goat, anti rabbit, and anti mouse diluted 1:1000 in blocking buffer. All antibodies were purchased from Santa Cruz Biotechnology (Santa Cruz, USA). After each antibody probing membrane was washed three times for $15 \mathrm{~min}$ in TBST buffer (0.1 M Tris $\mathrm{Ph} 8.0 ; 1.5 \mathrm{M} \mathrm{NaCl} ; 0.5 \%$ TritonX-100). Detection of membrane bound proteins was performed using West Pico Chemimiluminescent (Pierce, Rockford, USA).

Statistical analysis

Results are expressed as means \pm SEM. Statistical analysis was done using analysis on variance and two ways ANOVA test when appropriate. Differences with $p<0.05$ were considered statistically significant. 


\section{Results}

The effect of live Hp (cagA and vacA positive) strain with or without coincubation with exogenous CagA on the HSP70, Bax and Bcl-2 expression in MKN7 gastric epithelial cells

In this series of experiments, the MKN7 cells were exposed to live bacteria $\left(1 \times 10^{9}\right.$ per culture dish) over different periods of time starting from $3 \mathrm{~h}$ up to $48 \mathrm{~h}$. As expected the basal expression of HSP70 and mRNA for COX-2 in MKN7 cells was relatively high due to the intensive growth rate of that kind of cell type. As shown in Fig. 1 panel $b$, the $\operatorname{cag} A$ and $v a c A$ positive $H p$ strain inhibited in a timedependent manner the expression of HSP70 protein in MKN7 cells; the inhibitory effect on HSP70 was observed already at $3 \mathrm{~h}$ and the inhibitory effect of this strain of $\mathrm{Hp}$ on HSP70 expression was subsequently noted at $24 \mathrm{~h}$ and $48 \mathrm{~h}$ after exposure of cell culture to this bacteria. In the presence of $\mathrm{Hp}$ in the culture medium, the expression of HSP70 in MKN7cells was significantly downregulated at protein levels. Densitometry analysis confirmed that the expression of HSP70 protein in MKN7 cells was significantly decreased in cells coincubated with bacteria as compared to control cultures treated with saline instead of bacteria (Fig. 1, panel e). The expression for Bax increased $3 \mathrm{~h}$ after $\mathrm{Hp}$ infection, reaching its maximal level at $48 \mathrm{~h}$ of incubation. The expression of Bax was significantly increased when MNK7 cells were incubated with or without coincubation with recombinant CagA (Fig. 1c). Ratio of Bax protein over GAPDH protein confirmed that the expression of Bax protein was significantly increased when MNK7 cells were incubated with or without coincubation with recombinant CagA (Fig. 1 panel $f$ and Fig. 2 panel f).

As shown in Fig. 1 panel d, the expression for Bcl-2 was detected by immunoprecipitation in the MKN7 cells infected with $H p \operatorname{cag} A$ and $v a c A$ positive strain, was significantly diminished during the time period of $3 \mathrm{~h}$ up to $48 \mathrm{~h}$, with maximal inhibitory effect observed at $48 \mathrm{~h}$ of incubation. Densitometric analysis confirmed that the ratio of $\mathrm{Bcl}-2$ protein to GAPDH protein was significantly reduced when MKN7 cells were incubated with or without recombinant CagA (Fig. 1 panel g and Fig. 2 panel g).

Figure 2 panel $b$ shows that in the MKN7 cells which were incubated with a combination of $H p$ strain positive for $\operatorname{cag} A$ and $v a c A$ together with the addition of the recombinant CagA (10 $\mu \mathrm{g}$ per $1 \mathrm{ml}$ of RPMI 1640 medium), the decrease in the signal intensity for HSP70 was not significantly different at $3 \mathrm{~h}$ and $24 \mathrm{~h}$ following the incubation as compared with that of $H p$ alone (Fig. 1 panel b) without the addition of $\mathrm{CagA}$. However, when the incubation of the MKN7 cells with the $H p$ strain positive for $\operatorname{cagA}$ and vacA combined with exogenous CagA was prolonged up to $48 \mathrm{~h}$, a complete disappearance of the signal for HSP70 expression was observed. The ratio of HSP70 protein over GAPDH protein confirmed that expression of HSP70 was significantly reduced at 3 and $24 \mathrm{~h}$ when compared with the control group and that the expression was not detectable at all, when this $H p$ strain was coincubated with exogenous CagA for 48 h (Fig. 2, panel e).

The expression of Bax was significantly increased at 24 and $48 \mathrm{~h}$ after the addition of CagA to the cells infected with Hp cagA vacA positive strain. The addition of exogenous CagA resulted in a significant decrease in Bcl-2 expression with the most pronounced effect observed at 48 h (Fig. 2, panels c and d).

The effect of live Hp (cagA and vacA positive) and Hp (cagA and vacA negative) with or without coincubation with NS-398 on the COX-2 and Bax mRNA expression in MKN7 gastric epithelial cells

In MKN7 cells infected with $H p$ positive for $\operatorname{cagA}$ and $v a c A$, a significant increase in signal intensity for $\mathrm{COX}-2$ mRNA at $3 \mathrm{~h}, 6 \mathrm{~h}$ and $24 \mathrm{~h}$ of incubation was recorded as compared to control cells (Fig. 3, panel b). The increase in COX-2 expression was first observed $3 \mathrm{~h}$ after $H p$ infection and the maximal rise of COX-2 mRNA expression was recorded at $24 \mathrm{~h}$. The semi-quantitative ratio of COX-2 mRNA over $\beta$-actin mRNA confirmed that the expression of COX-2 reached the highest value in MKN7 cells incubated for $24 \mathrm{~h}$ with $H p$ strain positive for $\operatorname{cagA}$ and $v a c A$ (Fig. 3, panel c).

Figure 4 shows that after $3 \mathrm{~h}, 6 \mathrm{~h}$ and $24 \mathrm{~h}$ of co-incubation MKN7 cells with $H p$ positive for $c a g A$ and $v a c A$ and NS-398, the signal for expression of mRNA for COX-2 was almost identical at each study period. Additionally, we found that incubation of MKN7 cells with NS-398 only, significantly reduced COX-2 mRNA in these cells at $24 \mathrm{~h}$ upon selective COX-2 inhibitor administration (Fig. 4, panel b). Densitometry analysis of mRNA expression presented as ratio of mRNA for COX-2 over mRNA $\beta$-actin confirmed that the signal intensity for COX-2 mRNA was similar in control cells and those incubated with $H p \operatorname{cagA}$ and $v a c A$ positive with the addition of NS398 at 3, 6 and $24 \mathrm{~h}$ following the beginning of incubation with this COX-2 inhibitor. This ratio was significantly decreased when MKN7 cells were incubated only with NS-398 (Fig. 4, panel c).

The effects of co-incubation of $H p$ strain positive for cagA and vacA with NS-398 were then compared with those for $H p$ negative for $c a g A$ and $v a c A$ applied alone or co-incubated with NS-398. For this purpose, the MKN7 cells were incubated with live cagA and vacA negative $H p$ with or without NS-398 for 3, 6 and 24 h, exactly as in the 
(A)

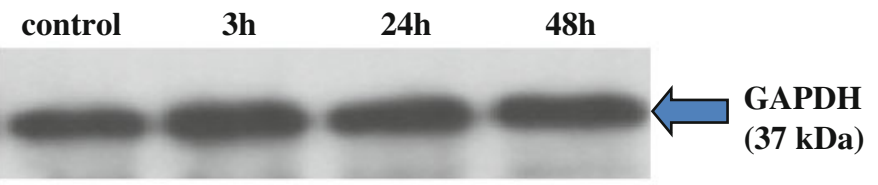

(B)

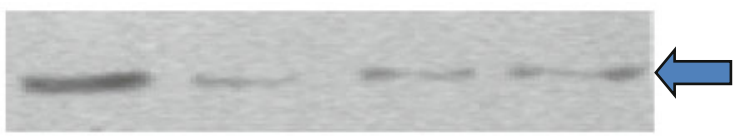

HSP70

$(70 \mathrm{kDa})$

(C)

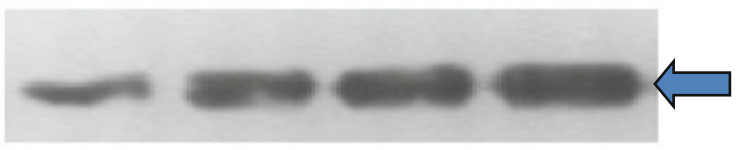

Bax

$(23 \mathrm{kDa})$

(D)

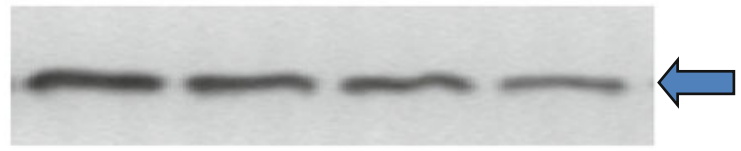

Bcl-2 (29 kDa)

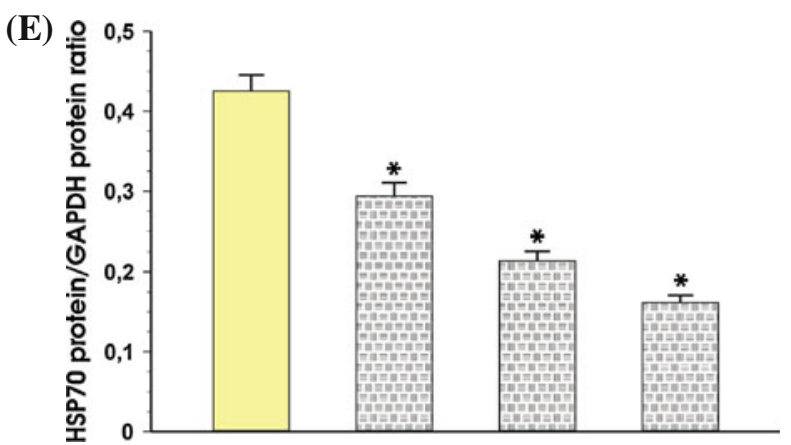

(F)

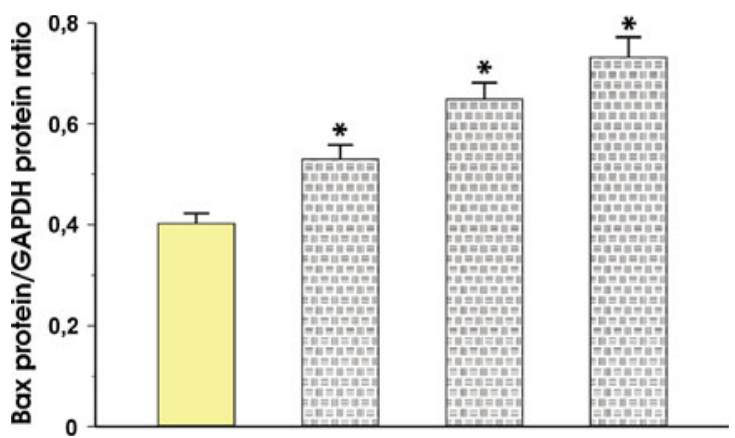

(G)

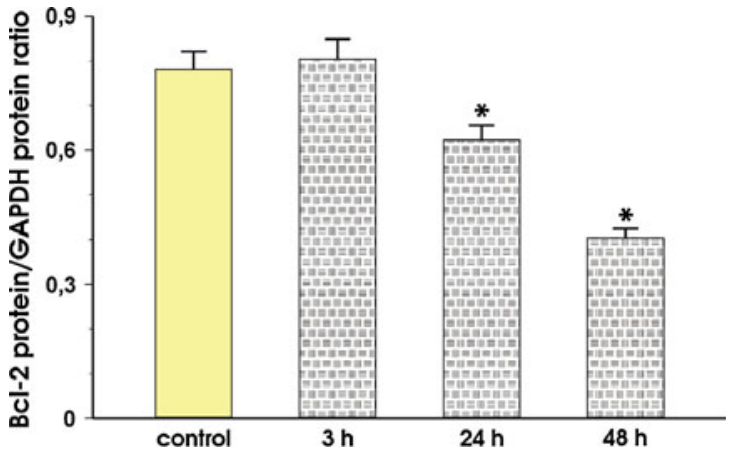

Fig. 1 Immunoprecipitation analysis of HSP70, Bax, Bcl-2 in total cellular proteins isolated from MKN7 cells exposed to $H p$ expressing cagA and vacA (left panel) and densitometric analysis of the signal for expression of HSP70, Bax and $\mathrm{BCl}-2$ protein. Total cellular proteins in the concentration of $10 \mu \mathrm{g}$ of was loaded per each lane. Proteins extracts from control cells (lane 1) and cells coincubated with $\mathrm{Hp}$

case of experiments with $H p$ strain positive for $\operatorname{cag} A$ and $v a c A$. In contrast to the $H p$ cagA and vacA positive strain which caused a time-dependent rise in COX-2 expression, the signal for COX-2 mRNA did not change during coinfection of the MNK7 cells with $H p$ cagA and vacA negative strain and this was confirmed by the ratio of mRNA for COX-2 over mRNA $\beta$-actin (Fig. 5 , panels b and c).

As illustrated in Fig. 6, panel b, COX-2 inhibitor, NS398 failed affect COX-2 expression at $3 \mathrm{~h}$ and $6 \mathrm{~h}$ but significantly decreased mRNA expression for COX-2 at $24 \mathrm{~h}$ of incubation. Similarly as presented in Fig. 4, NS398 significantly decreased the expression of COX-2 in MKN-7 cells non infected with $H p$. over the time period of $3 \mathrm{~h}$ (lane 2), $24 \mathrm{~h}$ (lane 3) and $48 \mathrm{~h}$ (lane 4) were separated in $12 \%$ SDS-polyacrylamide gel. Blots were probed with anti human HSP70, Bax, Bcl-2 antibody, respectively. Mean \pm SEM of four determinations. Asterisks $(p<0.05)$ indicate a significant increase or decrease above the control values

The expression of Bax mRNA increased $24 \mathrm{~h}$ after $\mathrm{Hp}$ infection and this effect was significantly inhibited by NS398 (Fig. 7, panel b). Ratio of Bax mRNA over $\beta$-actin mRNA confirmed that the expression of Bax mRNA was significantly increased in cells infected with $\mathrm{Hp}$ strain positive for $\operatorname{cagA}$ and $v a c A$ and this effect was significantly ameliorated by co-incubation with selective COX-2 inhibitor (Fig. 7, panel c).

\section{Discussion}

This study was designed to determine whether incubation of gastric mucosal cells with $H p$ influences the expression 
(A)

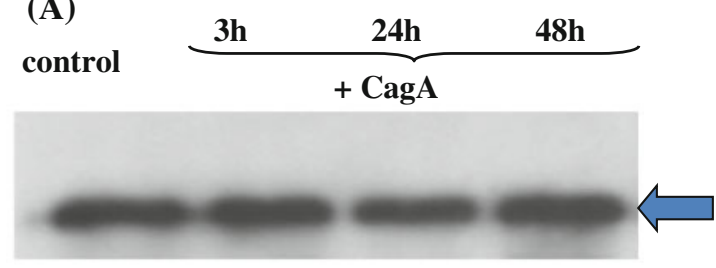

GAPDH

(37 kDa)

(B)

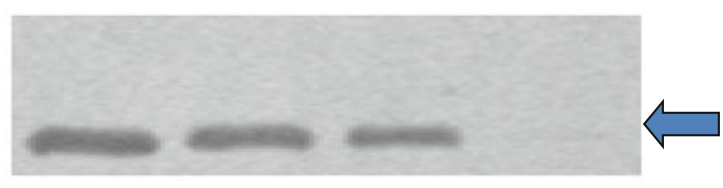

HSP70

(70 kDa)

(C)

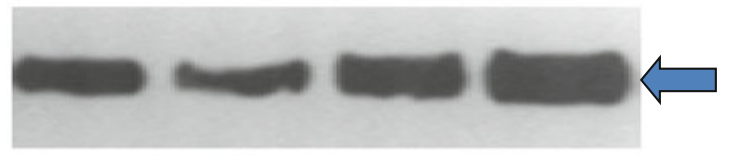

Bax

(23 kDa)

(D)

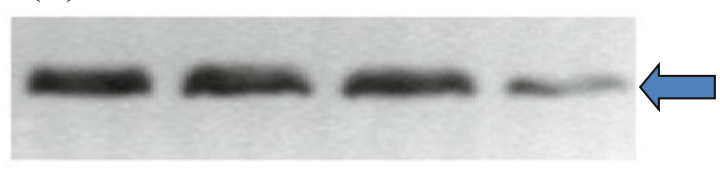

(E)

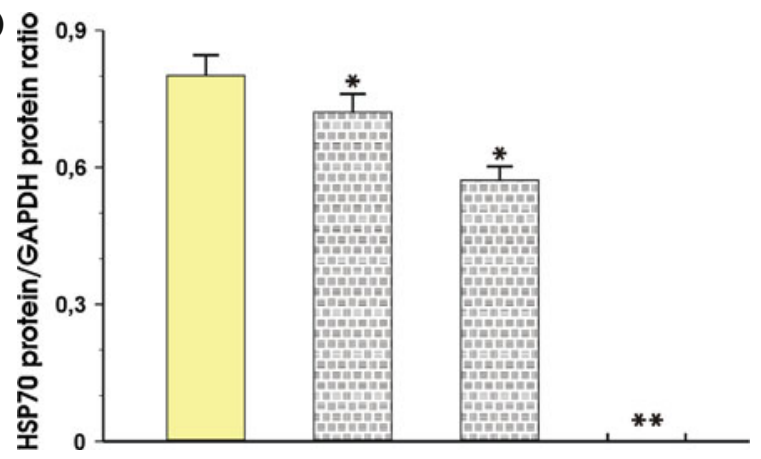

(F)

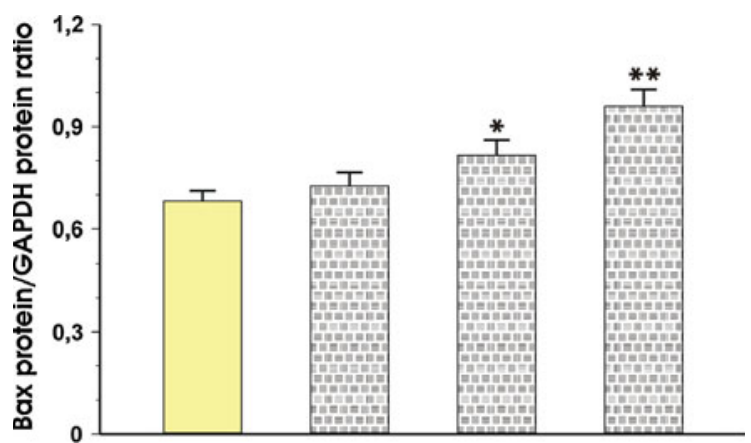

(G)

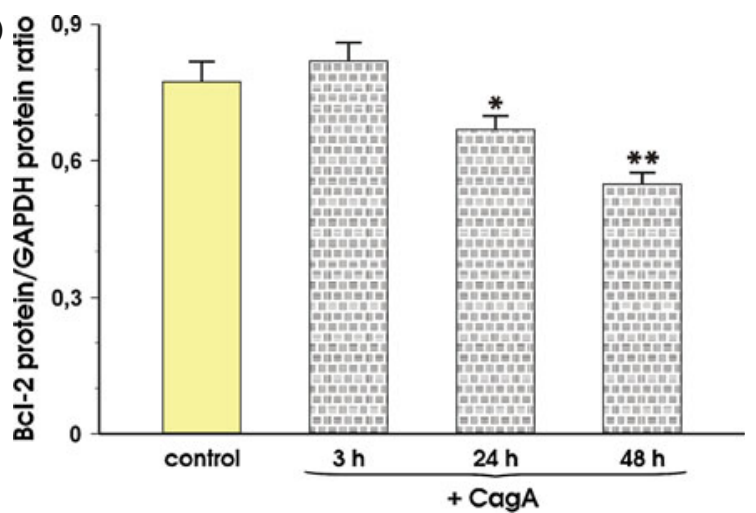

Fig. 2 Immunoprecipitation analysis of HSP70, Bax, Bcl-2 in total cellular proteins isolated from MKN7 cells coincubated with $H p$ expressing cagA and $v a c A$ with addition of exogenous CagA. Amount of $10 \mu \mathrm{g}$ of total cellular proteins was loaded per each lane. Proteins extracts from control cells (lane 1) and cells coincubated with $\mathrm{Hp}$ with addition of exogenous CagA over $3 \mathrm{~h}$ (lane 2), $24 \mathrm{~h}$ (lane 3) and

of HSP70, apoptosis related proteins Bax and Bcl-2 and expression of COX-2 in isolated gastric cells in vitro. Since the normal cultured human gastric epithelial cell line is not commercially available, we used for this purpose the gastric adenocarcinoma cell line MKN7, which is an established human gastric epithelium cell line for experimental studies in vitro conditions. Moreover, we attempted to determine the relationship between the apoptosis and COX-2 expression in this gastric adenocarcinoma cells infected with $H p$ strain and co-incubated with exogenous CagA to check whether recombinant CagA protein will aggravate the alterations in expression in HSP70, Bax and $\mathrm{Bcl}-2$ proteins in the absence and presence of $\mathrm{Hp}$.
$48 \mathrm{~h}$ (lane 4) were separated in $12 \%$ SDS-polyacrylamide gel. Blots were probed with anti human HSP70, Bax, Bcl-2 antibody, respectively. Mean \pm SEM of four determinations. Asterisks indicate a significant $(p<0.05)$ increase or decrease above the control values. Double asterisks indicate a significant $(p<0.05)$ increase or decrease above or below the values recorded at 3 and $24 \mathrm{~h}$, respectively

In vitro studies using gastric cancer cell lines have shown that incubation of isolated gastric cells with either live or dead $H p$ or sonicates of $H p$ cells leads to an induction of apoptosis [31,32] and results of our study with MKN7 cells are in agreement with these observations. At present, the mechanism by which $H p$ induces apoptosis in gastric cancer cells and interacts with HSP70 and COX-2 expression remains unknown.

There is increasing evidence that apoptosis plays an important role in the pathogenesis of a variety of infectious diseases. Although apoptosis as a process of cell death occurs in normal mucosal cells under physiological conditions, the excessive apoptosis results in tissue damage. 
(A)

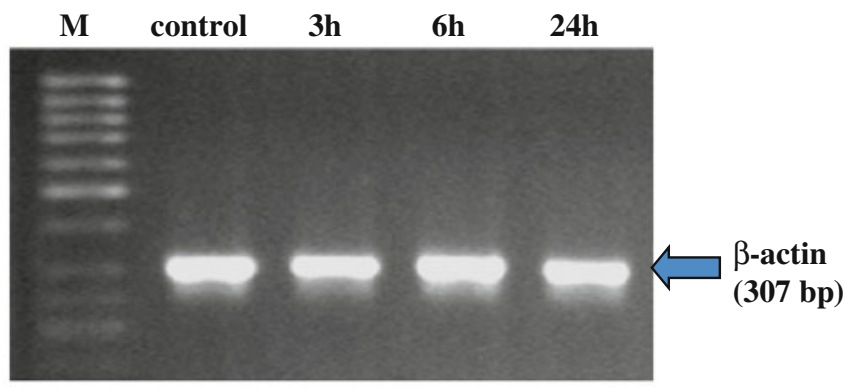

(B)

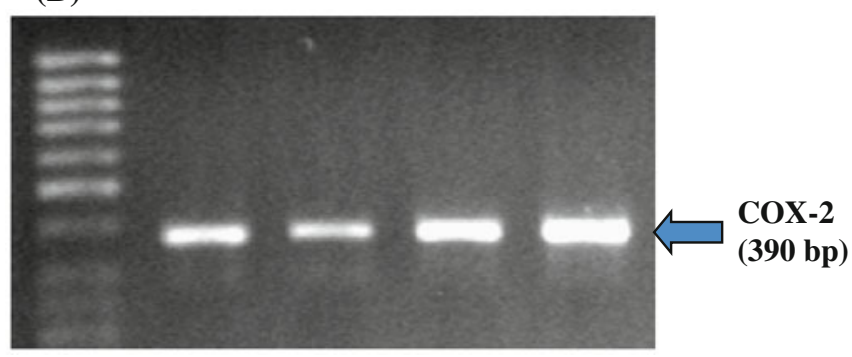

Fig. 3 RT-PCR analysis of mRNA expression for COX-2 in the MKN7 cells exposed to $H p$ expressing $c a g A$ and $v a c A$. a and b represent mRNA expression for $\beta$-actin and COX-2, respectively. Lane control means control cells (without infection). Following lanes represent mRNA expression for $\beta$-actin and COX-2 in MKN7 cells

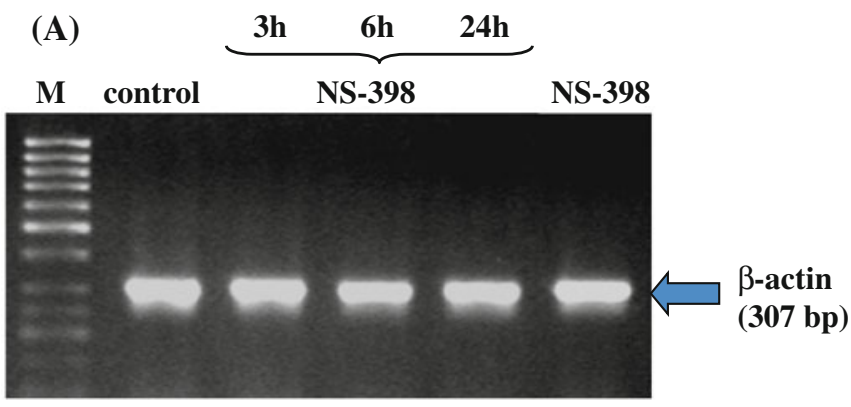

(B)

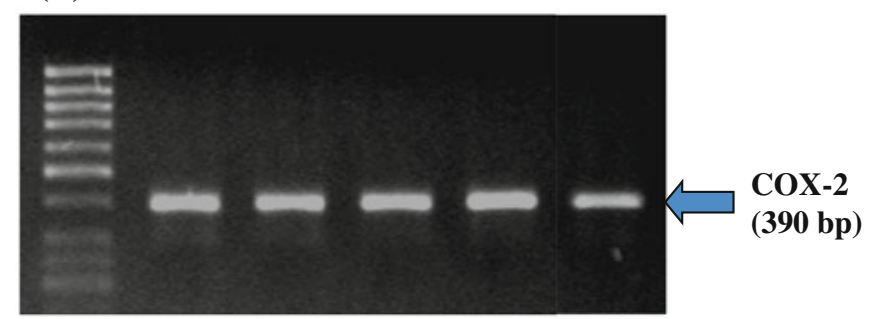

Fig. 4 RT-PCR analysis of mRNA expression for COX-2 in the MKN7 cells exposed to $H p$ expressing cagA and $v a c A$ and coincubated with the selective COX-2 inhibitor, NS-398. a and b Represent mRNA expression for $\beta$-actin and COX-2, respectively. Lane control means control cells without $H p$ infection and without coincubation with NS-398. Following lanes represent mRNA

\section{(C)}

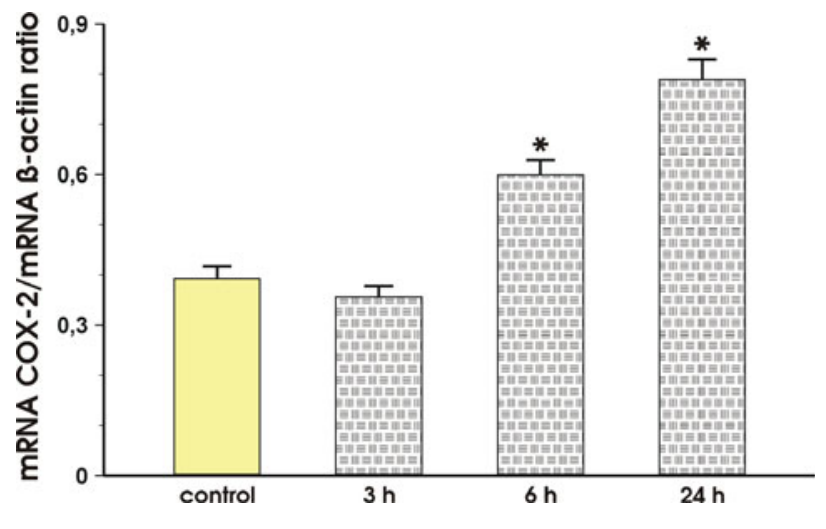

infected with $H p$ and incubated at 3, 6 and $24 \mathrm{~h}$, respectively. c Represents the ratio of COX- 2 mRNA over $\beta$-actin mRNA. Results are mean \pm SEM of five experiments. Asterisks indicate a significant change $(p<0.05)$ as compared to control

(C)

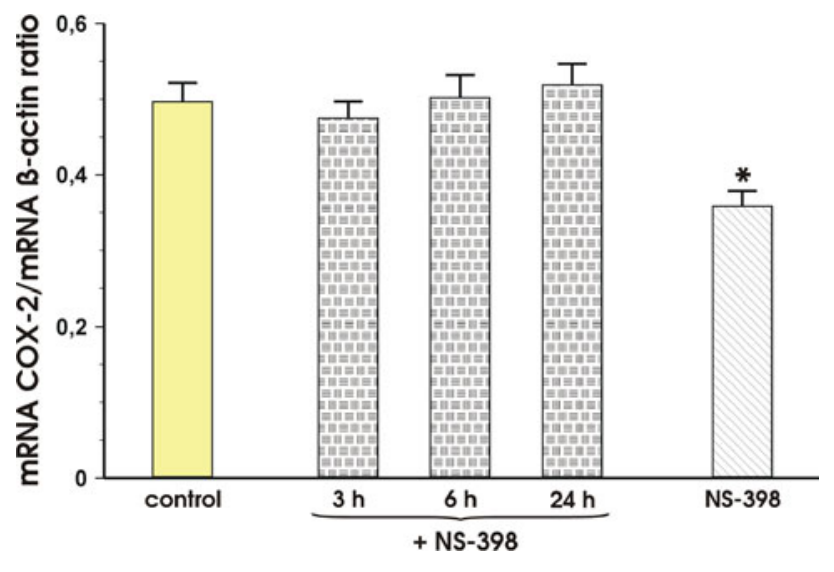

expression for $\beta$-actin and COX-2 in MKN7 cells infected with $\mathrm{Hp}$ and incubated with NS-398 for 3, 6 and $24 \mathrm{~h}$, respectively. Line NS-398 means MKN7 cells incubated with NS-398 only. $\mathbf{c}$ Represents the ratio of COX- 2 mRNA over $\beta$-actin mRNA. Results are mean \pm SEM of five experiments. Asterisk indicates a significant change $(p<0.05)$ as compared to control 


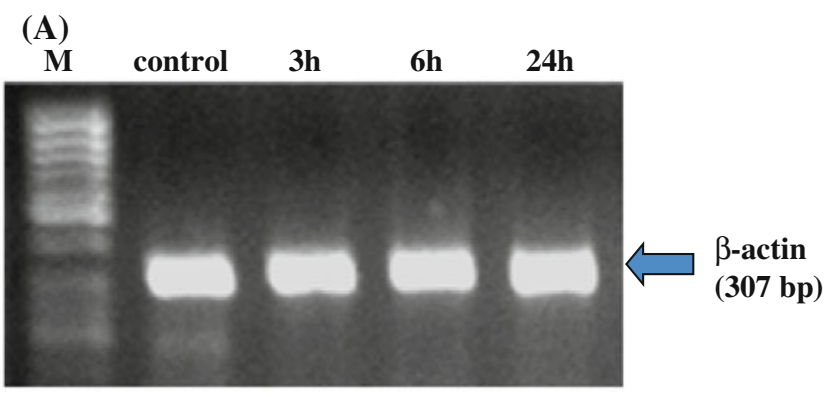

(B)

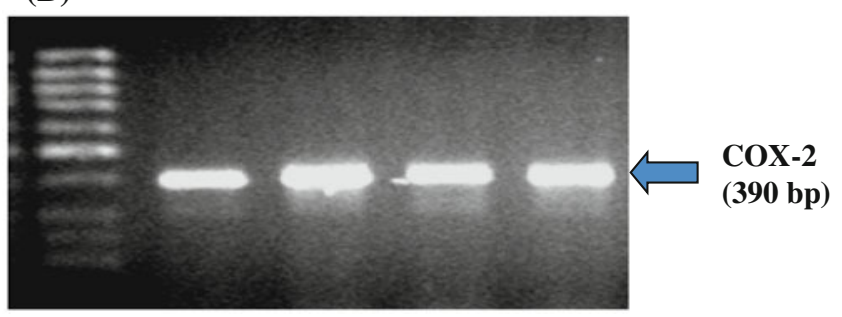

Fig. 5 RT-PCR analysis of mRNA expression for COX-2 in the MKN7 cells exposed to $H p$ cagA and vacA negative. a, b Represent mRNA expression for $\beta$-actin and COX-2, respectively. Lane control means control cells without infection. Following lanes represent

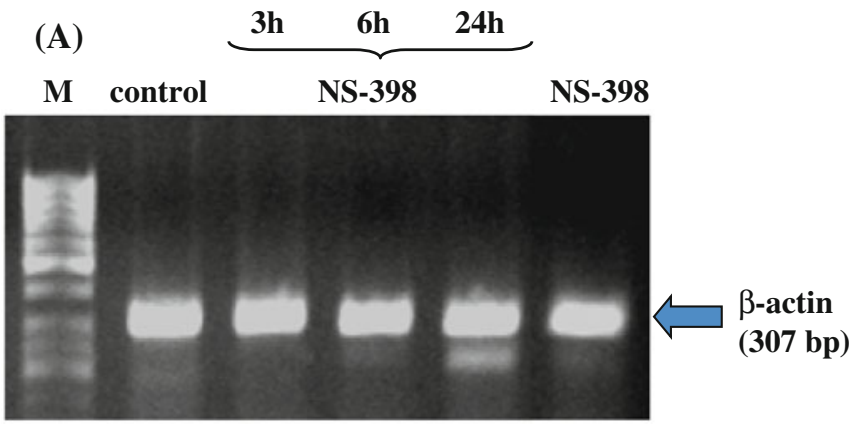

(B)

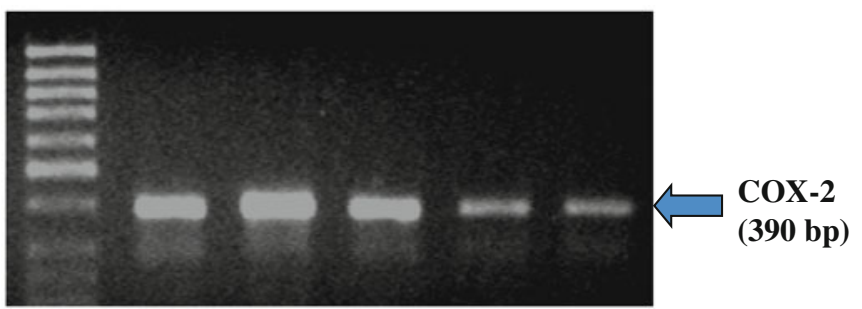

Fig. 6 RT-PCR analysis of mRNA expression for COX-2 in the MKN7 cells exposed to $H p \operatorname{cagA}$ and $v a c A$ negative strain and coincubated in the presence of NS-398. a, b represent mRNA expression for $\beta$-actin and COX-2, respectively. Lane Control means control cells without $H p$ infection and NS-398 addition. Following lanes represent mRNA expression for $\beta$-actin and COX-2 in MKN7

We extended our and others previous observation in vivo $[33,34]$ that $\operatorname{cagA}$ positive $H p$ strains induce apoptosis as evidenced by increasing expression of pro-apoptotic Bax
(C)

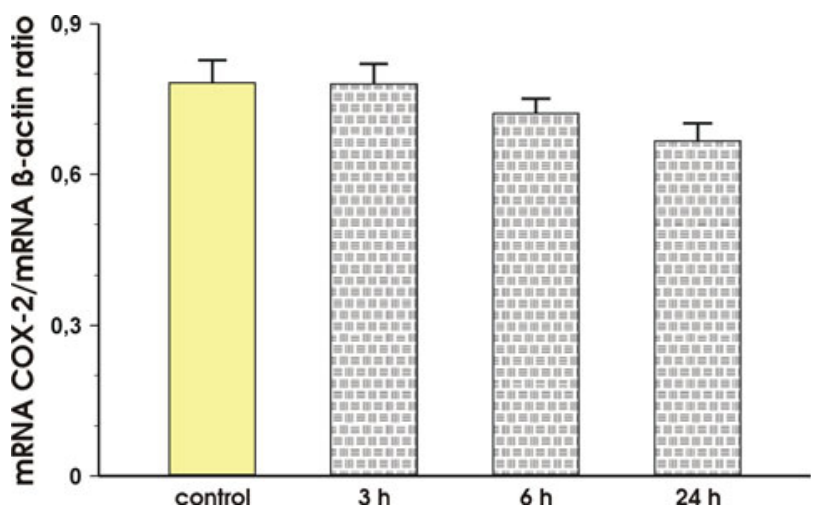

mRNA expression for $\beta$-actin and COX-2 in MKN7 cells infected with $H p$ and incubated at 3,6 and $24 \mathrm{~h}$, respectively. $\mathbf{c}$ Represents the ratio of COX- 2 mRNA over $\beta$-actin mRNA. Results are mean \pm SEM of five experiments
(C)

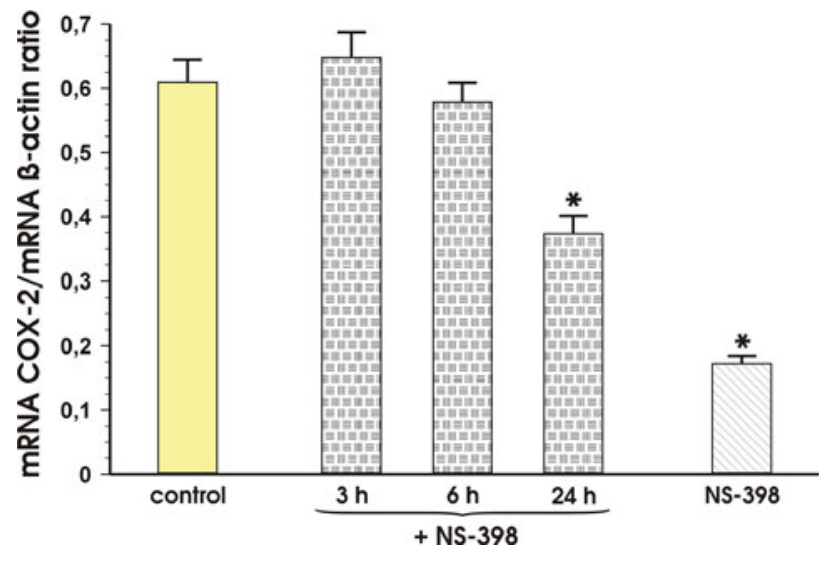

cells infected with $\mathrm{Hp}$ and co-incubated for 3, 6 and $24 \mathrm{~h}$ with NS398. Line NS-398 means MKN7 cells incubated with NS-398 only. c Represents the ratio of COX-2 mRNA over $\beta$-actin. Results are mean \pm SEM of 5 experiments. Asterisks indicate a significant change $(p<0.05)$ as compared to control

and decreasing expression for anti-apoptotic Bcl-2. In addition, CagA negative $H p$ strain also enhanced apoptosis suggesting that $\mathrm{CagA}$ is not a prerequisite for apoptosis to 


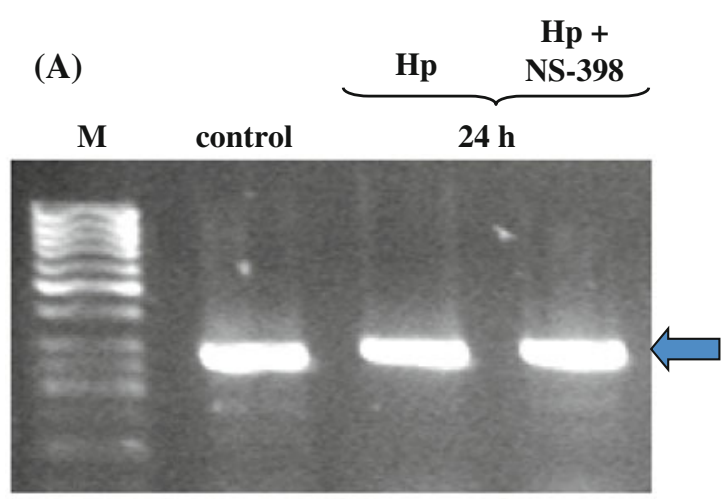

(B)

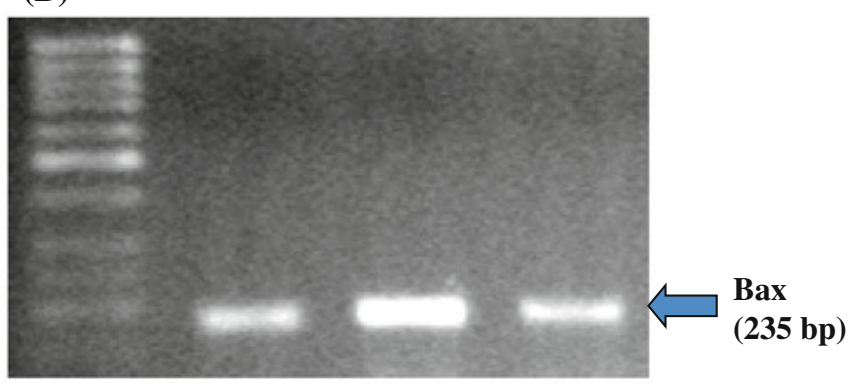

Fig. 7 RT-PCR analysis of mRNA expression for Bax in the MKN7 cells exposed to $H p$ expressing $\operatorname{cag} A$ and $v a c A$ in the absence and the presence of NS-398. a, b Represent mRNA expression for $\beta$-actin and Bax, respectively. Lane control means control cells without $\mathrm{Hp}$ infection and NS-398 addition. Following lane represents mRNA expression for $\beta$-actin and Bax in MKN7 cells incubated $24 \mathrm{~h}$ with $H p$ and the next lane shows mRNA expression for $\beta$-actin and Bax in

occur as suggested previously [35]. This notion is to some extent in keeping with observation by Peek et al. [36] and Zhang et al. [37] who reported that in patients infected with cagA positive $H p$ strains the apoptotic index was lower than in those with $\operatorname{cag} A$ negative $H p$ strains. In clear contrast, the gastric infection with $H p$ cagA positive strains was shown to induce an overexpression of proapoptotic proteins in the gastric mucosa $[38,39]$, similarly as in our present study with transformed cell line.

Most in vitro and animal studies have shown that both $H p$ cagA positive and $H p$ cagA negative strains enhanced apoptosis sometimes with no relation to CagA expression [27, 34, 37, 38] suggesting that our results with $H p$ infection of cancer cell line seems to mimic those obtained in normal gastric epithelial cells with respect to apoptosis at early time after infection. For example, Ashktorab et al. [38] reported that infection of gastric cells with a cagA positive $\mathrm{Hp}$ strain resulted in Bax translocation to mitochondria, caspase-3 activation, and ultimately cell death. Interestingly, $\mathrm{Hp}$ CagA positive strain induced apoptosis at 2 weeks after inoculation but this increased apoptosis almost declined to the baseline level after 12 months of inoculation in rats [40]. Therefore, it is not excluded that

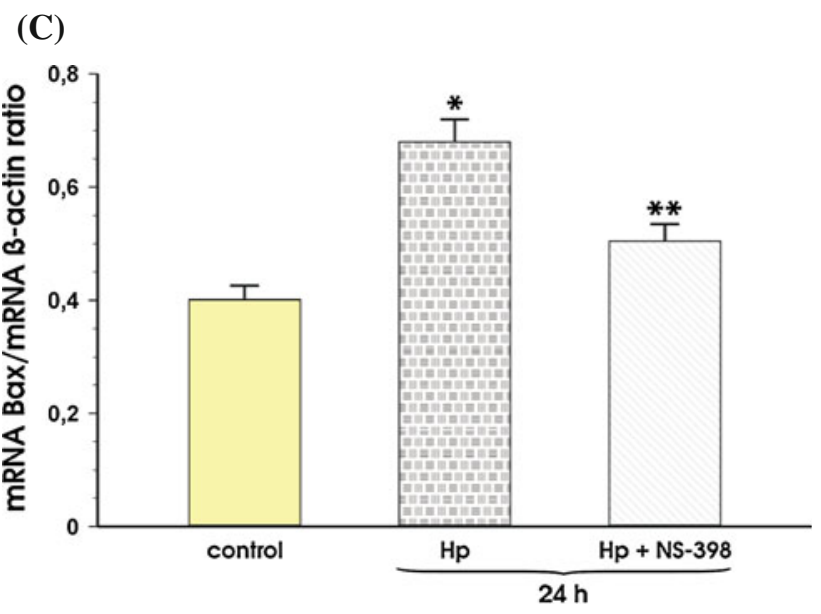

MKN7 cells incubated $24 \mathrm{~h}$ with the combination of $\mathrm{Hp}$ and NS-398. c Represents the ratio of Bax mRNA over $\beta$-actin mRNA. Results are mean \pm SEM of five experiments. Asterisks indicate a significant change $(p<0.05)$ as compared to control. Double asterisks indicate a significant change $(p<0.05)$ as compared to MKN7 cell incubation with $\mathrm{Hp}$ alone

the early enhancement in apoptosis process in both, normal and cancer cells may involve the formation of monochloramine $\left(\mathrm{NH}_{2} \mathrm{Cl}\right)$ observed in normal rat gastric epithelial cell line RGM-1 [41] and in gastric cancer cells MKN45 [42].

In addition besides CagA another cytotoxin of $\mathrm{Hp}$, VacA, has been reported to induce apoptosis [43]. Purified, recombinant VacA caused fragmentation of DNA in human gastric adenocarcinoma AGS cell line [13]. MKN7 cells were incubated with $H p$ expressing $c a g A$ and $v a c A$ and supplemented with exogenous $\mathrm{CagA}$, the trend in protein expression of Bax and Bcl-2 was similar to that observed in cells infected with $H p$ without CagA supplementation suggesting that exogenous CagA itself exerts not a direct stimulatory influence on gastric epithelial cells apoptosis. However, the most pronounced effect on apoptosis was observed when exogenous CagA was added to $H p$ positive for cagA and vacA cytotoxins suggesting that action of CagA may involve indirect effect, e.g. inhibition of HSP70. Indeed, CagA injected by $H p$ into the host epithelial cells was shown to "hijack" physiological signal transduction and caused pathological cellular response such as increased cell apoptosis, proliferation and morphology changes [26]. 


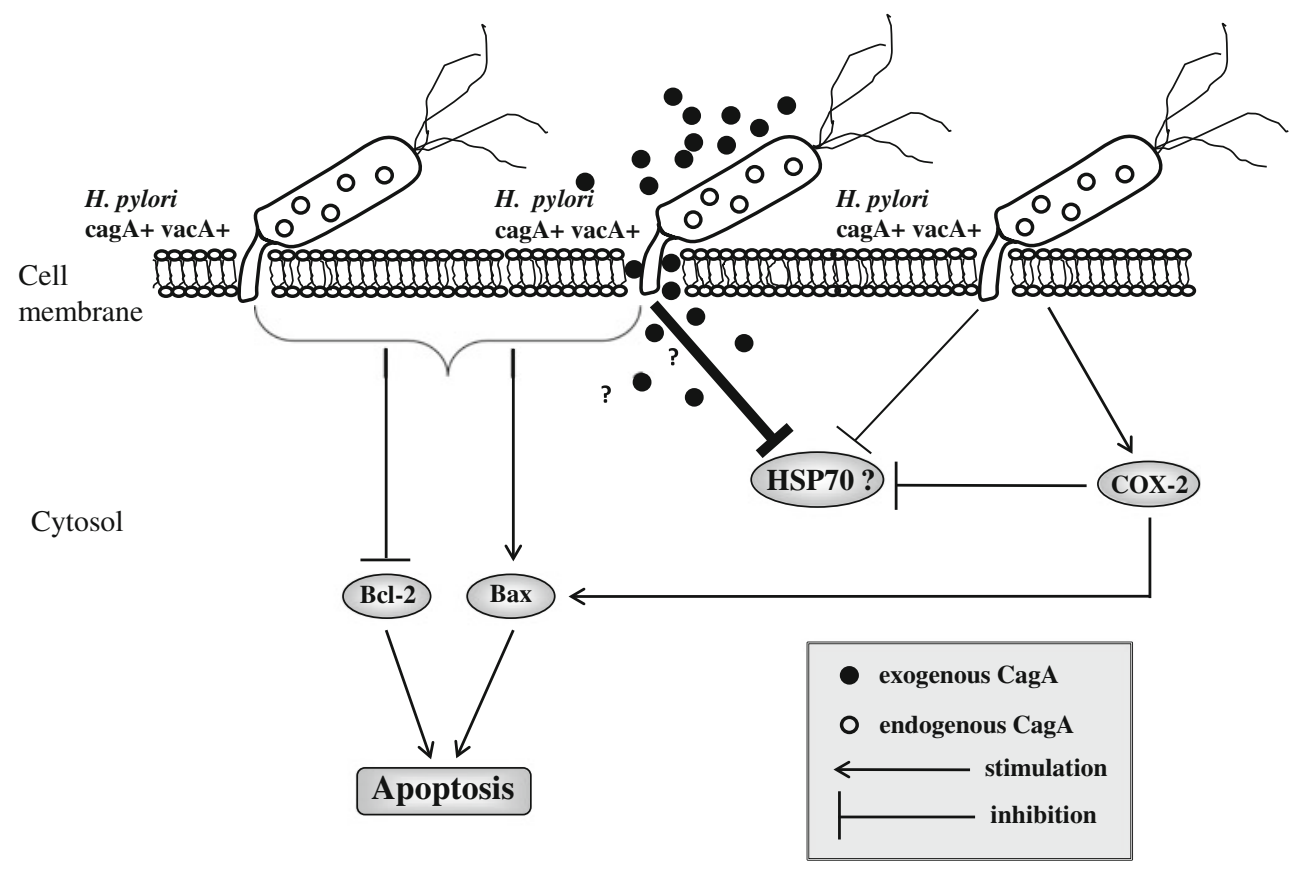

Fig. 8 Schematic hypothesis presenting model of $H p$ positive cagA and vacA strain interaction with human gastric epithelial MKN7 cells via enhancement of apoptosis, the inhibition of HSP70 and activation of COX-2 by this bacteria and its cytotoxin CagA

Our study indicates that this promotion of cell apoptosis by $H p$ strain positive for $\operatorname{cagA}$ and $v a c A$ is also evident in epithelial adenocarcinoma cell line MKN7. In addition, the CagA by itself can induce ROS production causing DNA damage, thus contributing to enhanced apoptosis in early stages of gastric carcinogenesis.

The major finding of our present study is that $H p$ can directly attenuate the expression of HSP70 in MKN7 cells which could by associated with the increase in apoptosis. Specific downregulation of HSP70 in MKN7 cells was observed, especially under condition where the live $H p$ expressing $\operatorname{cag} A$ and $v a c A$ was added to the cell culture and incubated for the period of $48 \mathrm{~h}$. Moreover, when the exposure of the cells with $H p$ strain positive for $c a g A$ and $v a c A$ was combined with exogenous CagA administration, a complete disappearance of the signal of HSP70 mRNA was recorded, suggesting that the addition of CagA to the cells infected with $H p$ positive for cagA and vacA, accelerated the inhibitory effect of bacteria and its cytotoxin on HSP70 expression (see, our hypothesis presented in Fig. 8). It should be noted, however, that cell incubation with recombinant CagA alone failed to affect the expression of mRNA for HSP70 (not shown), suggesting that the CagA protein itself does not exhibit inhibitory influence on HSP70 expression but exerts this inhibition only in the presence of $\mathrm{Hp}$. This is corroborative with the observation $[43,44]$ that the genes of the cag PAI actually encode for a functional type IV secretion system, by which $H p$ delivers the CagA protein directly into gastric epithelial cells. The possible molecular mechanism of the attenuation of HSP70 expression by $H p$ involves TFSS (type IV secretion system) and the subsequent activation of STAT3 (signal transducers and activators of transcription 3) pathway and activation of caspase- 3 dependent apoptosis pathway as has been recently proposed by our group, with regards to another human gastric epithelial cell line [45].

We conclude that $H p$ action involves the "injection" of CagA into the eukaryotic cells, or another not yet recognized mechanism related to the damage of cellular membrane and/or inhibitory effect of bacteria on tight by recruiting ZO-1 [46] that impaired cell junctions allowing for the transport of cytotoxin such as CagA by this bacteria and/or in the presence of this germ. Our working hypothesis is that $H p$ possesses an ability to deliver biologically active proteins such as CagA into eukaryotic cells, because the most pronounced inhibitory effect of $\mathrm{Hp}$ on HSP70 was observed in MKN7 cells additionally co-incubated with CagA. Our findings are, however, limited to the gastric adenocarcinoma cell line and further studies are needed to confirm this hypothesis in normal human gastric epithelial cells.

Our finding that $\mathrm{Hp}$ expressing cagA and vacA exerts direct effect on the structure of the epithelial cells causing its increased fragility and inhibits HSP70 expression suggests that downregulation of HSP70 and lack of its protective influence on cell defense system, might be one of the cause of many other $\mathrm{Hp}$-associated alteration of the $\mathrm{Bax} / \mathrm{Bcl} 2$ cellular equilibrium (Fig. 8). In normal rat gastric epithelial cells (RGM-1) $\mathrm{Hp}$ significantly attenuated the expression HSP70, whereas 
exposure of the $H p$-infected cells to short non-cytotoxic heat shock or geranylgeranylacetone (GGA) restored HSP70 expression in RGM-1 cells [47, 48]. Hp upregulates COX-2 mRNA expression in gastric cancer cells, and both premalignant and malignant gastric lesions demonstrated high COX-2 expression levels in vivo, suggesting that, $H p$-induced gastric carcinogenesis is associated with elevated expression of COX-2 in neoplastic gastric epithelium [49-51]. Herein, we have also demonstrated, that both $H p$ strains, namely $H p c a g A$ and $v a c A$ positive and $H p c a g A$ and vacA negative caused an up-regulation of COX-2 mRNA in MKN7 cells and this effect was inhibited by NS-398. Likewise, the NS-398 alone markedly inhibited the mRNA expression for COX2 whether or not cells were infected with $H p \quad c a g A$ and vacA negative strain. Since COX-2 overexpression is involved in gastric carcinogenesis, the suppression of COX-2 expression and activity might be useful in a chemoprevention strategy [52]. In our present in vitro study, NS-398 not only inhibited the upregulation of mRNA expression for COX-2 in $H p$-infected MKN7 cells, but also suppressed Bax expression. Li et al. [53] also showed that the selective COX-2 inhibitor attenuated the cell proliferation and apoptosis of the human gastric cancer cell line BGC-823, which may be attributed to the inhibition of cell cycle progress. On the other hand, Konturek et al. [54] reported that in gastric cancer patients 14-day treatment with selective COX-2 inhibitor a significant up-regulation of caspase- 3 mediating apoptotic cell death was observed. This indicates that $H p$ apparently promotes an apoptosis in vitro at early stage of infection but could exert opposite effect in vivo in long term infected patients with chronic and atrophic gastritis. COX-2 derived products and COX-2 inhibitors may differ in apoptotic response as to whether apoptosis is determined in isolated cells or in vivo condition.

In summary, we found that co-incubation of MKN7 epithelial cells with $H p$ without or with addition of CagA changed the equilibrium between Bax and Bcl-2 expression towards proapoptotic state (Bax) while simultaneously decreasing expression for anti-apoptotic Bcl-2. Thus it is hypothesized (Fig. 8) that besides HSP, also the PG generated via COX-2 expression and activity could be considered as another important activator of apoptosis triggered by $H p$ in the presence of CagA cytotoxin.

Acknowledgments This study was supported by grant from Polish Ministry of Science and Education 2 P05B 06226 to Aneta Targosz.

Open Access This article is distributed under the terms of the Creative Commons Attribution License which permits any use, distribution, and reproduction in any medium, provided the original author(s) and the source are credited.

\section{References}

1. Kerr JF, Wyllie AH, Currie AR. Apoptosis: a basic biological phenomenon with wide-ranging implications in tissue kinetics. $\mathrm{Br}$ J Cancer. 1972;26:239-57.

2. Staunton MJ, Gffney EF. Apoptosis. Basic concepts and disease relevance for the gastroenterologist. Gastroenterology. 1998;122:310-9.

3. Szabo I, Tarnawski AS. Apoptosis in the gastric mucosa: molecular mechanisms, basic and clinical implications. J Physiol Pharmacol. 2000;51:3-15.

4. Tsujimoto Y. Bcl-2 family: life-or-death switch. FEBS Let. 2000;466:6-10.

5. Antonsson B, Martinou J. The Bcl-2 protein family. Exp Cell Res. 2000;256:50-7.

6. Cepero E, Johnson BW, Boise LH. Cloning and analysis of Bcl-2 family genes. Meth Cell Biol. 2001;66:29-47.

7. Backert S, Ziska E, Brinkmann V, et al. Translocation of the Helicobacter pylori cagA protein in gastric epithelial cells by a type IV secretion apparatus. Cell Microbiol. 2000;2(2):155-64.

8. Windsor HM, O'Rourke KL. Bacteriology and taxonomy of Helicobacter pylori. Gastroenterol Clin North Am. 2000;29:633-48.

9. Akopyants NS, Clifton SW, Kersulyte D, et al. Analyses of the cag pathogenicity island of Helicobacter pylori. Mol Microbiol. 1998;28:37-53.

10. Censini S, Lange C, Xiang Z, et al. Cag, a pathogenicity island of Helicobacter pylori, encodes type I-specific and disease-associated virulence factors. Proc Natl Acad Sci. 1996;93:14648-6653.

11. Go MF, Crowe SE. Virulence and pathogenicity of Helicobacter pylori. Gastroenterol Clin North Am. 2000;29:649-70.

12. Maeda S, Mentis AF. Pathogenesis of Helicobacter pylori infection. Helicobacter. 2007;12(Suppl 1):10-4.

13. Cover TL, Krishna US, Dawn AI, Peek RM. Induction of gastric epithelial cell apoptosis by Helicobacter pylori vacuolating cytotoxin. Cancer Res. 2003;63:651-7.

14. Argent RH, Kidd M, Owen RJ, Thomas RJ, Limb MC, Atherton JC. Determinants and consequences of different levels of cagA phosphorylation for clinical isolates of Helicobacter pylori. Gastroenterology. 2004;127:514-23.

15. Guillemin K, Salama NR, Tompkins LS, Falkow S. Cag pathogenicity island-specific responses of gastric epithelial cells to Helicobacter pylori infection. Proc Natl Acad Sci. 2002;99:15136-41.

16. Al-Ghoul L, Wessler S, Hundertmark T, et al. Analysis of the type IV secretion system-dependent cell motility of Helicobacter pylori-infected epithelial cells. Biochem Biophys Res Comm. 2004;322:860-6.

17. Stein M, Rappuoli R, Covacci A. Tyrosine phosphorylation of Helicobacter pylori cagA antigen after cag-driven host cell translocation. Proc Natl Acad Sci. 2000;97:1263-8.

18. Shibata W, Hirata Y, Yoshida H, et al. NF-kappaB and ERKsignaling pathways contribute to the gene expression induced by cagPAI-positive-Helicobacter pylori infection. World J Gastroenterol. 2005;11:6134-43.

19. Rokutan K. Role of heat shock protein in gastric mucosal protection. J Gastroenterol Hepatol. 2000;15:D12-7.

20. Robert J, Menoret A, Basu S, Cohen N, Srivastava PR. Phylogenetic conservation of the molecular and immunological properties of the chaperons HSP96 and HSP70. Eur J Immunol. 2001;31:186-95.

21. Konturek JW, Fischer H, Konturek PC, et al. Heat shock protein to (HSP70) in gastric adaptation to aspirin in Helicobacter pylori infection. J Physiol Pharmacol. 2001;52:153-64. 
22. Canoz O, Belenli O, Patriroglu TE. General features of gastric carcinomas and comparison of HSP70 and NK cell immunoreactivity with prognostic factors. Pathol Oncol Res. 2000;8:262-9.

23. Church RD, Fleshman JW, McLeod HL. Cyclooxygenase 2 inhibition in colorectal cancer therapy. $\mathrm{Br} \mathrm{J}$ Surg. 2003;90:1055-67.

24. Kim JM, Kim JS, Jung HCH, Song IS, Kim CHY. Upregulated cyclooxygenase-2 inhibits apoptosis of human gastric epithelial cells infected with Helicobacter pylori. Dig Dis Sci. 2000;45:2436-43.

25. Xia H, Talley NJ. Apoptosis in gastric epithelium induced by Helicobacter pylori infection: implications in gastric carcinogenesis. Am J Gastroenterol. 2001;96:16-26.

26. Handa O, Naito Y, Yoshikawa T. CagA protein of Helicobacter pylori: a hijacker of gastric epithelial cell signaling. Biochem Pharmacol. 2007;73:1697-702.

27. Zhang H, Fang DCH, Lan CHH, Luo YH. Helicobacter pylori infection induces apoptosis in gastric cancer cells through the mitochondrial pathway. J Gastroenterol Hepatol. 2007;22:1051-6.

28. Ding SZ, Minohara Y, Fan XJ, et al. Helicobacter pylori infection induces oxidative stress and programmed cell death in human gastric epithelial cells. Infect Immun. 2007;75:4030-9.

29. Kim TIL, Lee YCH, Lee KH, et al. Effect of nonsteroidal antiinflammatory drugs on Helicobacter pylori-infected gastric mucosae of mice: apoptosis, cell proliferation and inflammatory activity. Infect Immun. 2001;69:5056-63.

30. Cha B, Lim JW, Kim KH, Kim H. HSP90beta interacts with Rac1 to activate NADPH oxidase in Helicobacter pylori-infected gastric epithelial cells. Int J Biochem Cell Biol. 2010;42:1455-61.

31. Wagner S, Beil W, Westermahn J, et al. Regulation of gastric epithelial cell growth by Helicobacter pylori: evidence for a major role of apoptosis. Gastroenterology. 1997;113:1836-47.

32. Fan X, Crowe SE, Behar S, Gunasena H, et al. The effect of class II major histocompatibility complax expression on adherence of Helicobacter pylori and induction of apoptosis in gastric epithelial cells: a mechanism for I helper cell type-1 mediated damage. J Exp Med. 1998;10:1659-69.

33. Brzozowski T, Konturek PC, Mierzwa M, et al. Effect of probiotics and triple eradication therapy on the cyclooxygenase (COX)-2 expression, apoptosis, and functional gastric mucosal impairment in Helicobacter pylori-infected Mongolian gerbils. Helicobacter. 2006;11:10-20.

34. Cabral MM, Mendes CM, Castro LP, et al. Apoptosis in Helicobacter pylori gastritis is related to cagA status. Helicobacter. 2006;11:469-76.

35. Karabay G, Nacar A, Can F, et al. Apoptosis and proliferation in gastric epithelium due to Helicobacter pylori: an immunohistochemical and ultrastructural study. Acta Gastroenterol Belg. 2006; 69:191-6.

36. Peek RM Jr, Moss SF, Tham KT, et al. Helicobacter pylori $\operatorname{cagA}^{+}$strains and dissociation of gastric epithelial cell proliferation from apoptosis. J Natl Cancer Inst. 1997;89:863-8.

37. Zhang H, Fang DC, Wang RQ, Yang SM, Liu HF, Luo YH. Effect of Helicobacter pylori infection on expression of Bcl-2 family members in gastric adenocarcinoma. World J Gastroenterol. 2004;15:227-330.

38. Ashktorab H, Frank S, Khaled AR, Durum SK, Kifle B, Smoot DT. Bax translocation and mitochondrial fragmentation induced by Helicobacter pylori. Gut. 2004;53:805-13.
39. Bartchewsky W Jr, Martini MR, Squassoni AC, et al. Effects of Helicobacter pylori infection on the expressions of Bax and Bcl-2 in patients with chronic gastritis and gastric cancer. Dig Dis Sci. 2010;55(111-116):38.

40. Li H, Andersson EM, Helander HF. Reactions from rat gastric mucosa during one year of Helicobacter pylori infection. Dig Dis Sci. 1999;44:116-24.

41. Naito Y, Yoshikawa T, Fuji T, et al. Monochloramine-induced cell growth inhibition and apoptosis in a rat gastric mucosal cell line. J Clin Gastroenterol. 1997;25(Suppl 1):S179-85.

42. Suzuki H, Seto K, Mari M, et al. Monochloramine induced DNA fragmentation in gastric cell line MKN45. Am J Physiol. 1998;275:G712-6.

43. Reider G, Merchant JL, Haas R. Helicobacter pylori cag-type IV secretion system facilitates corpus colonization to induce precancerous conditions in Mongolian gerbils. Gastroenterology. 2005; 128:1229-42.

44. Asahi M, Azuma T, Ito S, et al. Helicobacter pylori CagA protein can be tyrosine phosphorylated in gastric epithelial cells. J Exp Med. 2000;191:593-602.

45. Pierzchalski P, Krawiec A, Ptak-Belowska A, Baranska A, Konturek SJ, Pawlik WW. The mechanism of heat-shock protein 70 gene expression abolition in gastric epithelium caused by Helicobacter pylori infection. Helicobacter. 2006;11:96-104.

46. Amieva MR, Vogelmann R, Covacci A, Tompkins LS, Nelson WJ, Falkow S. Disruption of the epithelial apical-junctional complex by Helicobacter pylori CagA. Science. 2003;300:1430-4.

47. Yeo M, Park HK, Kim DK, et al. Restoration of heat shock protein70 suppresses gastric mucosal inducible nitric oxide synthase expression induced by Helicobacter pylori. Proteomics. 2004;4:3335-42.

48. Hirakawa T, Rokutan K, Nikawa T, Kishi K. Geranylgeranylacetone induces heat shock proteins in cultured guinea pig gastric mucosal cells and rat gastric mucosa. Gastroenterology. 1996;111:345-57.

49. Romano M, Ricci V, Memoli A, et al. Helicobacter pylori upregulates cyclooxygenase- 2 mRNA expression and prostaglandin $\mathrm{E}_{2}$ synthesis in MKN 28 gastric mucosal cells in vitro. J Biol Chem. 1998;273:28560-3.

50. Sung JJ, Leung WK, Go MY, et al. Cyclooxygenase-2 expression in Helicobacter pylori-associated premalignant and malignant gastric lesions. Am J Pathol. 2000;157:729-35.

51. Bartchewsky W Jr, Martini MR, Masiero M, et al. Effect of Helicobacter pylori infection on IL-8, IL- $1 \beta$ and COX-2 expression in patients with chronic gastritis and gastric cancer. Scand J Gastroenterol. 2009;44:153-61.

52. Thun MJ, Henley SJ, Patrono C. Nonsteroidal anti-inflammatory drugs as anticancer agents: mechanistic, pharmacologic, and clinical issues. J Natl Cancer Inst. 2002;94:252-66.

53. Li Q, Peng J, Zhang GY. Effect of a selective COX-2 inhibitor on cell proliferation and apoptosis in human gastric cancer cell line BGC-823. Zhong Nan Da Xue Xue Bao Yi Xu. 2008;33:1123-8.

54. Konturek PC, Kania J, Konturek JW, Nikiforuk A, Konturek SJ, Hahn EG. H. pylori infection, atrophic gastritis, cytokines, gastrin, COX-2, PPAR gamma and impaired apoptosis in gastric carcinogenesis. Med Sci Moni. 2003;9:SR53-66. 